\title{
Human Accessibility Modelling Applied to Protected Areas Management
}

\author{
Carolina Franco Esteves ${ }^{1}$, Silvio Frosini de Barros Ferraz ${ }^{2 *}$, \\ Katia Maria Paschoaletto Micchi de Barros Ferraz ${ }^{2}$, Mauro Galetti ${ }^{3} \&$ David Martin Theobald ${ }^{4}$
}

\author{
${ }^{1}$ Centro Conservação e Manejo de Fauna - CEMAFAUNA - CAATINGA, \\ Universidade Federal do Vale do São Francisco - UNIVASF, Petrolina, PE, Brazil \\ ${ }^{2}$ Departamento de Ciências Florestais, Escola Superior de Agricultura Luiz de Queiroz-ESALQ, \\ Universidade de São Paulo - USP, Piracicaba, SP, Brazil \\ ${ }^{3}$ Laboratório de Biologia da Conservação, Departamento de Ecologia, Universidade Estadual Paulista - UNESP, \\ Rio Claro, SP, Brazil
}

${ }^{4}$ Department of Fish, Wildlife, and Conservation Biology, Colorado State University, Fort Collins, CO, USA

\begin{abstract}
Natural protected areas in tropical regions are considered important refuges for flora and fauna, and the only remaining habitat for many species. However, these areas still suffer from numerous human impacts, whether by illegal hunting, logging or tourism. Mapping areas of greater human access and its potential effect to wildlife should be considered as strategy for management in protected areas. This study aimed to generate a human accessibility map for the Anchieta Island, for purposes of zoning and management. We evaluated the impact of human presence (tourism) on the occurrence of wildlife at Anchieta Island by using the concept of human accessibility. Accessibility model was correlated with estimated travel-time using Pearson's Correlation and showed significant positive relationship $(r=0.714)$ between accessibility model and travel time observed in the field. Thus, the accessibility methodology can be a valuable tool to analyze human impacts on wildlife through hunting and logging in protected areas.
\end{abstract}

Key words: Tourism, Cost-Distance, Anchieta Island State Park, Accessibility, Zoning.

\section{Introduction}

Human activities have direct impacts on vertebrate wildlife populations and influence species conservation (Beale \& Monaghan 2004). Therefore mapping areas of greater human access and its potential effect to wildlife needs to inform potential strategies for managing protected areas. The ease of access to these areas in tropical countries encourages the development of illegal activities such as hunting, smuggling, fishing, logging and extraction of natural products for trade (Joppa et al. 2008).

The increase of tourism in Brazil has attracted tourists to protected areas in recent years (Kinker 2005). Many authors argue that negative impacts are inherent to recreational use in these parks (Vickery 1995; Leung \& Marion 2000). Even the most alert tourists leave marks and disrupt the

*Send correspondence to: Silvio Frosini de Barros Ferraz Departamento de Ciências Florestais,

Escola Superior de Agricultura Luiz de Queiroz - ESALQ, Universidade de São Paulo - USP,

Av. Padua Dias, 11, CEP 13418-900, Piracicaba, SP, Brazil e-mail: silvio.ferraz@usp.br ecosystem without realizing it. Thus, for proper management of protected areas it must reconcile both the public demands and the prevention of undesirable impacts on wildlife and their habitat (Hammitt \& Cole 1998).

The impacts of tourism can have socio-cultural, economic or environmental dimensions (Mason 2008). Regarding environmental impacts, its nature and severity in protected areas vary by the type of recreation and can be direct or indirect, or even synergistic or compensatory (Newsome et al. 2005). We summarized the main effects of recreational use in protected areas on Table 1.

Human accessibility has been proposed as a way to analyze the human impact on the distribution of vertebrate populations (Carver et al. 2002). This impact is measured by the distance of the closest point of access, and considering also the access difficulties (e.g. barriers or other landscape features).

The literature presents a lot of definitions for the term accessibility and in general it depends on the focus of the study. The term accessibility means "capable of being 


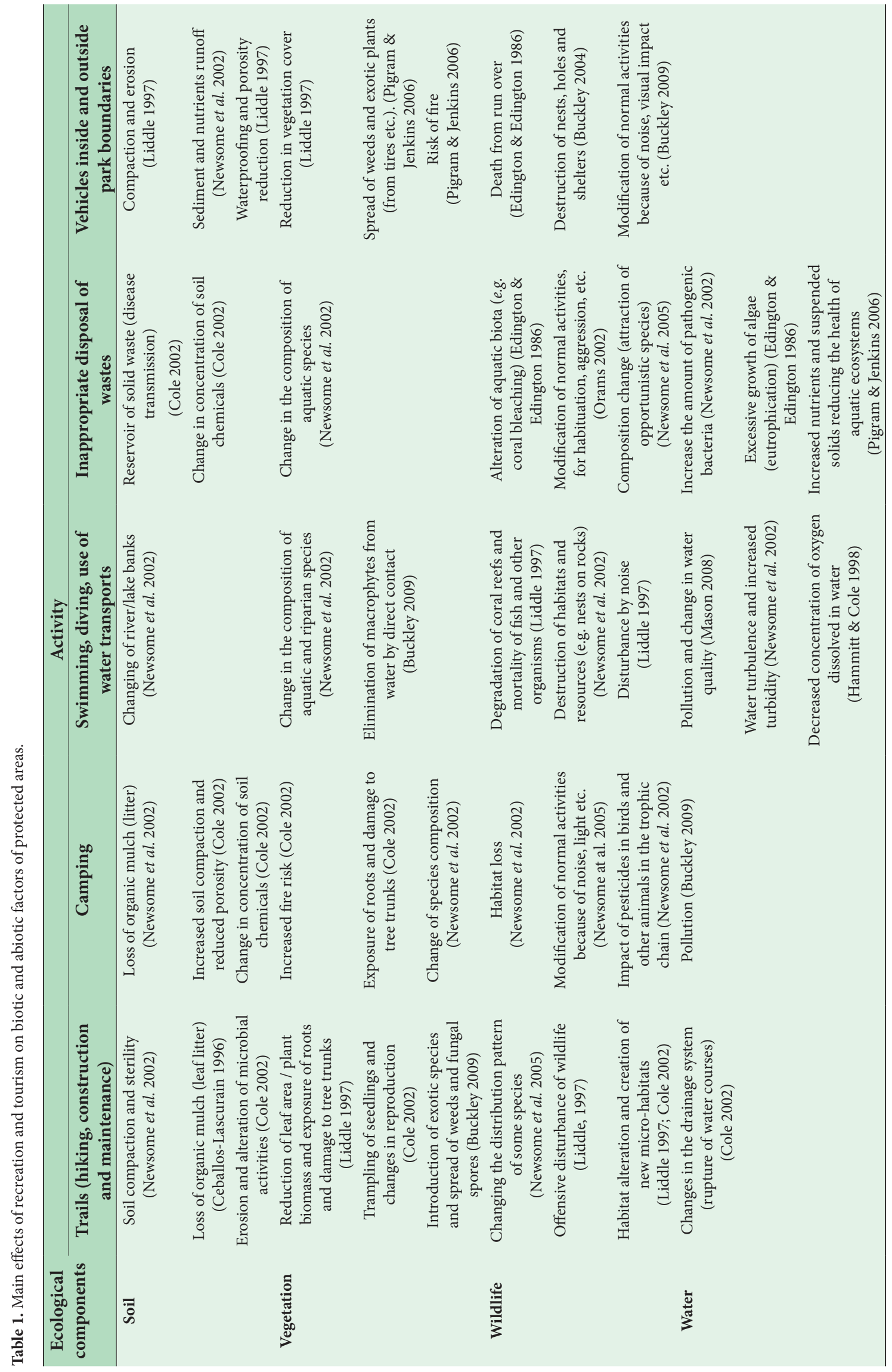


reached", implying a measure of the proximity between two points (Ingram 1971). Methods to measure accessibility are well developed in public service (e.g. Harris 2001; Weber \& Kwan 2003) and also in the evaluation of land use change (e.g. Nagendra et al. 2003; El-Geneidy \& Levinson 2007). These methods are, however, rarely used directly in the planning of wildlife conservation and most of them focus only on landscape connectivity and animal dispersion (Lin 2009; Pinto \& Keitt 2009). The accessibility model takes into account the distance covered from an origin point, going by the available areas for the human movement by through the access/path of smaller resistance (Theobald et al. 2010).

The distance that separates the destination from the origin point affects the degree of relative accessibility. Factors in addition to distance can be included, such as slope, land cover, presence of road or trail, etc. These information can be combined with distance, which can allow us to explore cost-distance based effects (Theobald 2009). Land cover may have different cost values according to vegetation density and soil substrate, thus influencing human movement in the landscape (Adriaensen 2003; Jobe \& White 2009). Cost-distance is also called the effective distance, because it presents a more realistic measure of movement. It considers the resistance of the landscape and not only the extent in straight line (Euclidian distance; Lin 2009).

The growth of ecotourism in tropical areas has attracted tourists for protected areas but these public parks are poorly prepared to attend the demand conciliating recreation and conservation goals (Terborgh \& Van Schaik 2002). The measurement of human physical accessibility is fundamental concerning conservation strategies. According to Vickery (1995), the growing interest in outdoor recreation and the resulting increase in visitation in protected areas can cause considerable degradation and environmental disturbances. The author recommends that the permission for access to these sites should only happen with careful planning.
Furthermore, accessibility could be incorporated as conservation strategy through parks spatial zoning system, allocating areas for specific levels and intensities of human activities and for protection (Eagles et al. 2002). Fennell \& Dowling (2003) considers the environmental zoning of protected areas as a key tool in planning and managing these areas. For this, zoning must consider all activities that occur within the park boundaries, such as land cover, recreation and tourism. Conservation objectives can reach better results if recreational activities are concentrated in certain areas of the park. The provision of facilities such as tables and showers may encourage the tourists' permanence in these areas and thus reduce the pressure in sensitive areas (Vickery 1995). This practice of releasing human access to certain areas of the park and restrict the use of some sensitive sites may be crucial to conserve rare and endemic species to the region.

Our overall goal was to create a model of human physical accessibility using Anchieta Island State Park (PEIA) as a study area. This model can be used to estimate the impacts of human influence on vertebrate population, for instance, and can be applied to other protected areas.

\section{Material and Methods}

The PEIA is located in Ubatuba municipality, north coast of São Paulo state, Brazil ( $45^{\circ} 02^{\prime} 20^{\prime \prime}$ to $45^{\circ} 04^{\prime} 59^{\prime \prime} \mathrm{W}$; $23^{\circ} 31^{\prime} 31^{\prime \prime}$ to $23^{\circ} 33^{\prime} 40^{\prime \prime} \mathrm{S}$; Figure 1). The park covers 828 ha, has a long history of human occupation and held a prison in the 1930s. All its area belongs to Anchieta Island State Park (PEIA), created in 1977. The island vegetation is composed of coastal Atlantic rainforest and some areas of disturbed vegetation are occupied by ferns. To prevail guidelines for management and conservation of PEIA's natural resources, balancing tourism development, four different zones of use were adopted in the Management Plan (Guillaumon et al. 1989): 1) intangible zone; 2) extensive use zone; 3 ) recovery zone and 4 ) intensive use zone.

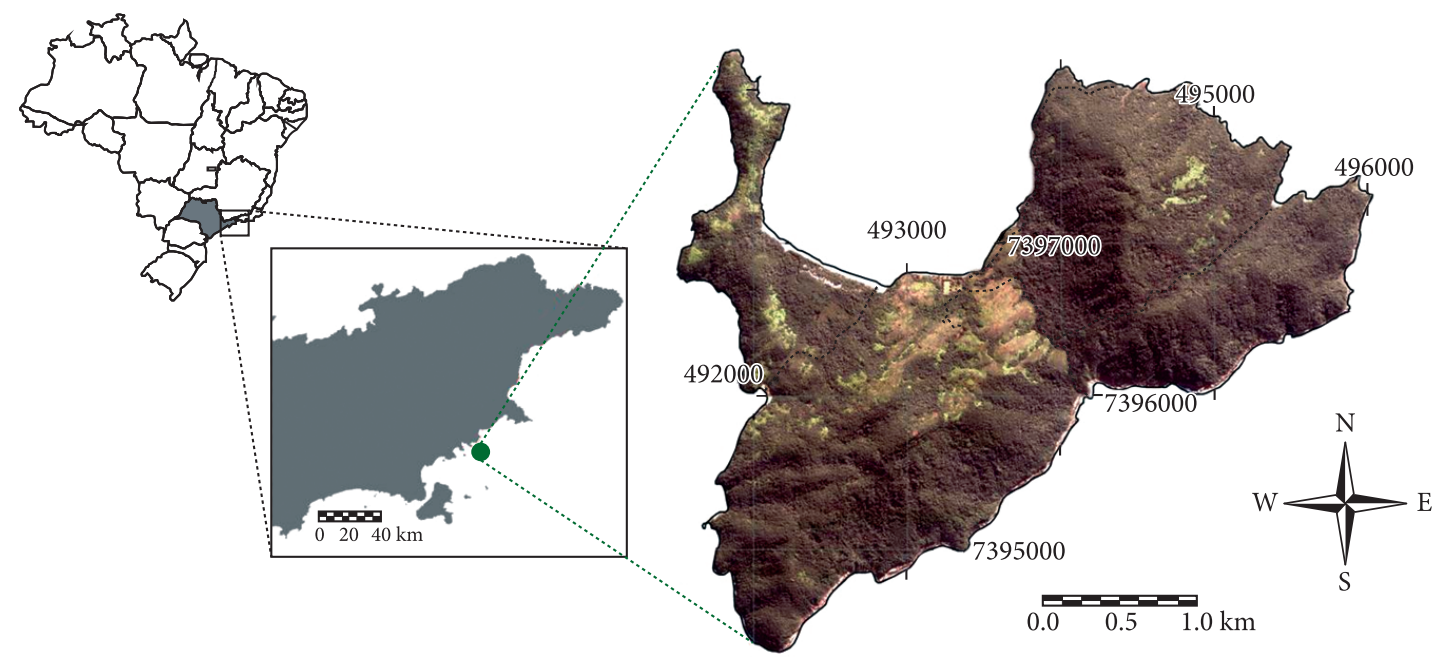

Figure 1. Image of Anchieta Island, São Paulo State, Brazil. Dashed lines indicate the trails of the park. 
The influence of human presence at Anchieta Island was evaluated through accessibility concept, based on costdistance in GIS environment (ArcGIS 9.2). Accessibility model takes into account the distance from an origin point, passing through available areas for human movement for the access/path of least resistance. Low cost values represent low effort to reach the aimed site. High values represent the high cost of human physical effort to reach these areas, influenced by natural barriers (topography) or anthropogenic (constructions).

The calculation of accessibility based on cost-distance in GIS environment requires raster input maps: 1) a file of resistance/friction map which specifies the cost of movement between cells (e.g. slope map) and 2) a file of the origin location(s), from which the cumulative cost of moving to each target cell is measured. The algorithm function of the cost-distance uses the resistance file and calculates a value for each cell, which is the lowest cumulative cost from this cell to the closest source cell (Theobald 2009). This function calculates the cost of moving from the center of one cell to another, computed as (Mitchell 1999) (Equation 1):

$$
\mathrm{C}_{\mathrm{i}}=\left(\mathrm{c}_{\mathrm{i}} \times \frac{\mathrm{R}}{2}\right)+\left(\mathrm{c}_{\mathrm{j}} \times \frac{\mathrm{R}}{2}\right)
$$

where $C_{i}$ equals the cost-distance value of the cell $i, c_{i}$ is the cost value (from resistance file) of the source cell of the movement $i, c_{j}$ is the cost value (from resistance file) of the source cell of the movement $j$ and $R$ equals the cell size or resolution. The construction of the accessibility model considers that a person likely will travel some distance along a road or trail (DTT) and then travel certain distance off trail (DTOT) to reach the target location.
In this study the accessibility model was built taking into account the distance of the closest point of access (park trails and buildings) and the access difficulties (slope and land cover with $5 \mathrm{~m}$ cell resolution). The steps to construct the accessibility model were the following (Figure 2): 1) the DTT cost-distance was calculated considering the trails as access routes to park areas and the area occupied by buildings as the input source. There are no paved roads on the park, and they are all considered walking trails. As the tracks have different degrees of difficulty along the way due to type of soil substrate, steepness, etc., we set weights for each track, following the concept of Analytical Hierarchy Process (AHP) (Saaty 1977). AHP is a systematic method to assist in making complex decisions and in the comparison of alternatives, justifying the choice. A matrix was assembled by comparing the tracks, according to a scale of degrees of difficulty (Table 2). The final weight obtained for each track was calculated as the sum of weights from each class, divided by the total sum (all classes), multiplied by 20 and converted to integers. High weight or resistance signifies low permeability.

The second step (2) was to allocate cost values of the trails (weighted) to all adjacent areas within PEIA, using Cost Allocation function; (3) in DTOT maps of land cover (based on Aranha 2011) and slope of PEIA were combined. Because each class of land cover map embraces different degrees of difficulty along the way, we set weights for each cover type. The land cover classes considered in this study were the following: a) Restinga, b) Ferns, c) Beach, d) Miconia vegetation, e) Initial stage forest of succession, f) Intermediate stage forest, g) Advanced stage forest, h) Buildings, i) Rocky coast and j) Wetland. Similarly, a

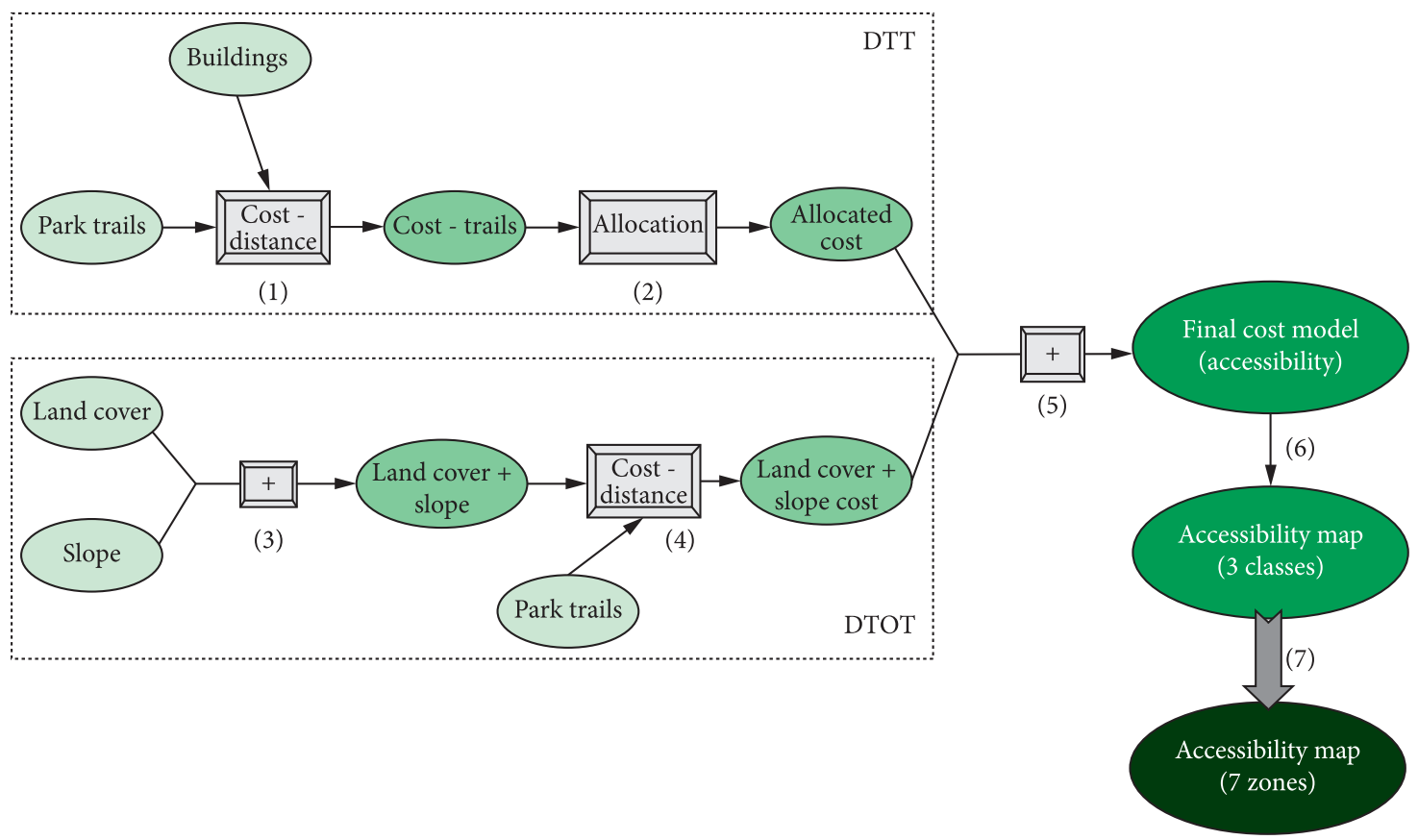

Figure 2. GIS procedures to obtain the accessibility model of Anchieta Island, SP, with steps from 1 to 7 detailed in the text. 
Table 2. Decision-making matrix adopted for park trails and land cover weights in PEIA.

\begin{tabular}{lccc}
\hline \multicolumn{1}{c}{ Land cover class } & Final weight & Park trail & Final weight \\
\hline Restinga & 3 & Saco Grande & 1 \\
Ferns & 8 & Sul & 1 \\
Beach & 1 & Pedra do navio & 5 \\
Miconia & 2 & Leste & 10 \\
Initial stage forest & 7 & Represa & 3 \\
Intermediate stage forest & 5 & & \\
Advanced stage forest & 4 & & \\
Buildings & 1 & & \\
Rocky coast & 8 & & \\
Wetland & 3 & & \\
\hline
\end{tabular}

matrix was assembled (Table 2) through a comparison between classes of land cover, according to the degrees of difficulty (AHP ; Saaty 1977); (4) from the resulting map we calculated the cost-distance by considering the park trails as source of access; (5) the maps of cost allocated in DTT, and cost of land cover and of slope in DTOT were then combined to generate the accessibility gradient map for PEIA, with areas of greater and lesser access throughout Anchieta Island; (6) the final accessibility map was then classified according to three levels considering the same range of values: short hike (1-2 hours), day hike (2-4 hours) and long hike ( $>4$ hours); (7) because each access level has different types of vegetation the island was divided into seven zones, considering the degree of access and vegetation type.

To validate the accessibility model in the field, we recorded the travel-time by starting from the main park entrance of tourists (building areas) to 18 random points distributed within PEIA. The location of the random points were chosen according to vegetation classes and distance from origin in order to cover all classes of accessibility (10 points in short hike, 5 in day hike and 3 in long hike). The course was carried out firstly over the park trails and then off trails to the mentioned points. Pearson's correlation analysis was performed including the travel-time to the specific sites distributed on the island and its cost-distance values.

\section{Results}

The output values for the accessibility model for PEIA comprised values of physical costs ranging from 2 to 16 . We reclassified the accessibility map into seven zones (Figure 3), which showed that the areas of easier access correspond with those most degraded. The class with the largest area is the one of day hike ( $309 \mathrm{ha}$ ), followed by long hike class (280 ha) and short hike (213 ha).

Each access zones presented distinct characteristics in altitude, slope, land cover and vegetation composition. The first zone represents the touristic entry of the island and is the most accessible site (short hike), characterized by flat terrain and low elevation areas. It is also the most heterogeneous in vegetation composition, encompassing restinga vegetation, forest in advanced and intermediate regeneration stage, and disturbed vegetation (ferns). The day hike zones comprise different regeneration stages and fern fields, with average slope and higher elevations. The long hike zones are steeper, with average elevation. The latter comprise the most homogeneous vegetation composition, with dense forest and some fern spots. Recommendations and conservation objectives proposed for each zone described in this study are shown in Table 3.

Our analysis showed positive significant correlation between accessibility model and travel-time observed in the field $(r=0.714 ; \mathrm{n}=18 ; p<0.01)$. The higher the value of cost in the model presented, the greater the time taken to access the desired location. For instance, the minimum time computed to reach a low cost local on the island (average 3.1) was six minutes and the maximum time to reach a place of high cost (average 7.2) was 39 minutes, which implies that higher cost values takes more travel-time than lower cost values.

\section{Discussion}

The results corroborate and emphasize the success of the model adopted for representation of the human real accessibility at the Anchieta Island. The accessibility model presented in this study can be a valuable tool to assess the human impact in protected areas, and it has considerable implications for wildlife conservation (hunting) and deforestation (logging) (Chin \& Bennett 2000; Peres \& Lake 2003). The fact that areas of easier access in PEIA correspond with those most degraded can be linked to the disturbance history of the island, starting from Indigenous occupation and mainly during the period of the prison operation (for 25 years). Today the use of the park by visitors has to be the primary focus of management planning, presenting the objectives of the protected area, as well as involving the tourists in the conservation strategy.

Areas with extensively disturbed vegetation (anthropogenic field and forests in early stages of succession) could be recovered from habitat restoration with native seedlings or seeds, when located in areas with steeper slopes (to prevent soil erosion) (Gandolfi \& Rodrigues 2007). Forest regeneration is also indicated in flat areas with heavy traffic 


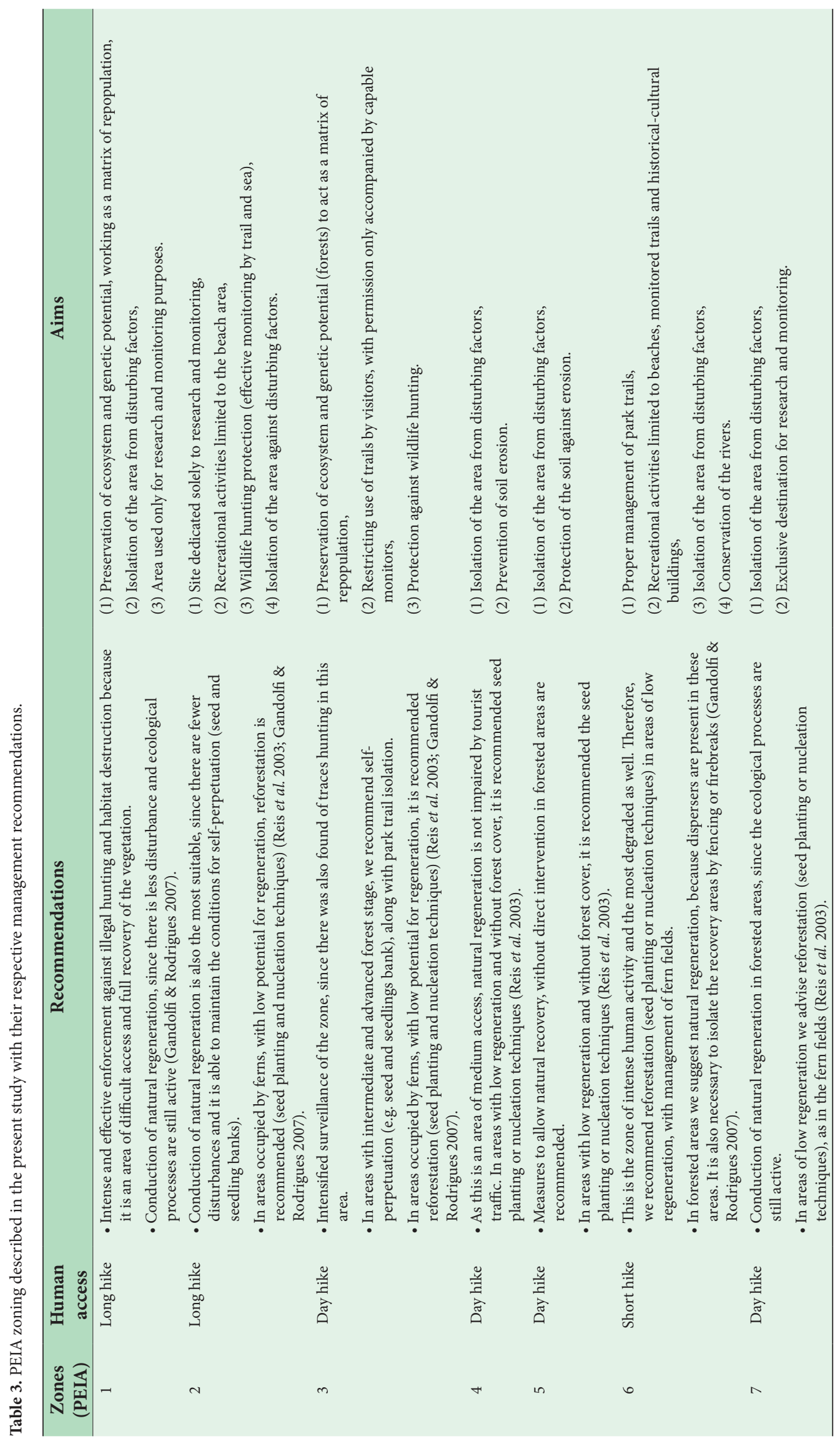




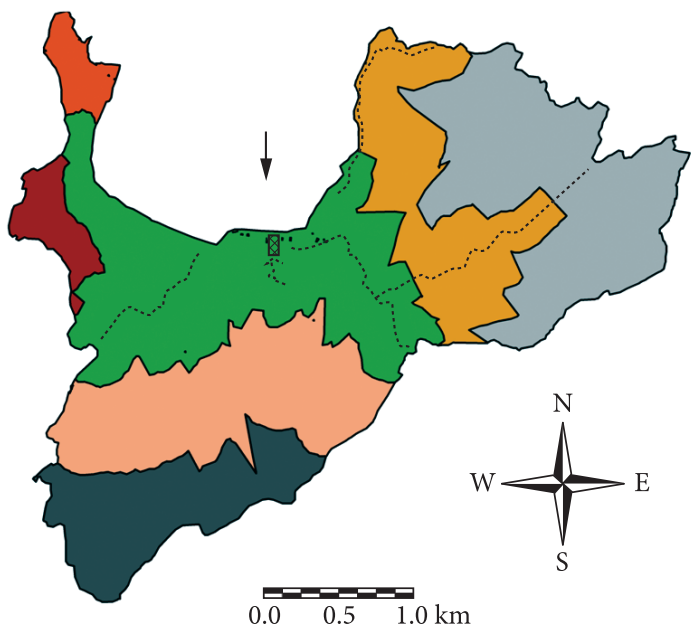

$\because \because$ Park trails $\otimes$ Buildings
Zones
$\square$ Zone 1 - long hike $\square$ Zone 2 - long hike
$\square$ Zone 3 - day hike $\square$ Zone 4 - day hike
$\square$ Zone 5 - day hike $\square$ Zone 6 - short hike
$\square$ Zone 7 - day hike

Figure 3. Zoning of the Anchieta Island, SP, classified into seven accessibility areas, detailing the construction area (old prison) and park trails. The dark arrow indicates the location of PEIA entrance.

of tourists for speeding up regeneration. The problem with soil erosion is generally lower in these flatter areas. Thus, the implementation of measures to enable natural regeneration would be more appropriate because, besides the lesser financial cost, the movement of tourists in specific areas of the island is already restricted. In zones with less disturbed vegetation and with more advanced stage of regeneration, the restriction of tourist access when necessary is appropriate to preserve the ecosystem.

Zone 6 presents areas requiring more protection due to easy access (short hike zone). Those areas are coincident to most visited sites in PEIA. Since 1998, the landing site, the entry and length of stay of visitors are controlled. Even so, there is still the need to develop standards for the park, allowing the structure of ordered visitation, to restrict specific areas to be restored and monitored permission for interpretative trails.

It is important to consider that zoning would be enhanced with the inclusion of vegetation communities mapping of more vulnerable and the most sensitive animal species. An example would be restricting access to potential nesting sites. In addition, zoning allows the temporal or seasonal access to certain areas, depending on the dynamics and behaviour of species (Vickery 1995). In times of PEIA's visitation peak, December and January, access to some areas of the park would be narrower to ensure the preservation of some species.
The accessibility model created for the Anchieta Island allowed identifying more appropriate measures of management and protection, in function of local physical characteristics of the area, of current land cover and of the use of those areas for tourism. As PEIA management program dates 20 years ago, the data obtained by this study on accessibility in the Island should be considered in its review. Our results should serve as base for the development and implementation of strategies for environmental conservation, and effective recommendations that complement the park's management processes. Furthermore the model presented in this study can be applied in other tropical protected areas, as a form of supporting in future management strategies of these parks, according to the particular characteristics of each one.

The impact of human presence was analyzed in this study by accessibility, especially considering tourism, which is the most common factor in PEIA. Still, accessibility models can also be used to analyze other human impacts on protected areas, such as gaming and logging, for example.

\section{Acknowledgements}

We thank the Fundação de Amparo à Pesquisa do Estado de São Paulo for financial support (FAPESP 2008/01866-3 and 2008/03724-1) as well as PEIA's staff for believing the study and for logistical support. We also thank Leandro B. Aranha who kindly provided digital maps of PEIA and all field assistants who helped us.

\section{References}

Adriaensen F et al., 2003. The application of "least-cost" modeling as a functional landscape model. Landscape Urban Plan, 64:233-247. http://dx.doi.org/10.1016/ S0169-2046(02)00242-6

Aranha LB, 2011. Modelagem da dinâmica da paisagem do Parque Estadual da Ilha Anchieta, Ubatuba, SP: subsídios para o plano de restauração. [Dissertação]. Piracicaba: Escola Superior de Agricultura "Luiz de Queiroz", Universidade de São Paulo. 161 p.

Beale C \& Monaghan P, 2004. Human disturbance: people as predation-free predators? Journal of Applied Ecology, 41:335343. http://dx.doi.org/10.1111/j.0021-8901.2004.00900.x

Buckley RC, 2009. Ecotourism: principles and practices. Oxford: CABI International. 368 p.

Carver S, Evans A \& Fritz S, 2002. Wilderness attribute mapping in the United Kingdom. International Journal of Wilderness, 8:24-29.

Ceballos-Lascurain H, 1996. Tourism, ecotourism and protected areas: the state of nature-based tourism around the world and guidelines for its development. Gland: IUCN. 301 p.

Chin CLM \& Bennett EL, 2000. Beside the beaten track: effects of increased accessibility on wildlife and patterns of hunting in Sarawak. In: Leigh M (ed.). Borneo 2000: environment, conservation and land. Kuching, Sarawak: Institute of South East Asian Studies. p. 29-40. 
Cole DN, 2002. Ecological impacts of wilderness recreation and their management. In: Hendee JC \& Dawson CP (eds.). Wilderness management: stewardship and protection of resources and values. 3th ed. Golden: Fulcrum Publishing. p. 413-459.

Eagles PFJ, McCool SF \& Haynes CDA, 2002. Sustainable tourism in protected areas: guidelines for planning and management. Cambridge: IUCN. http://dx.doi. org/10.1079/9780851995892.0000

Edington JM \& Edington MA, 1986. Ecology, recreation and tourism. Cambridge: Cambridge University Press. 200 p.

El-Geneidy AM \& Levinson DM, 2007. Mapping accessibility over time. Journal of Maps, 2007:76-87. http://dx.doi. org/10.4113/jom.2007.63

Fennell D \& Dowling RK, 2003. Ecotourism policy and planning. Wallingford: CAB International. $361 \mathrm{p}$.

Gandolfi S \& Rodrigues RR, 2007. Metodologias de restauração florestal. In Fundação Cargill (coord.). Manejo ambiental e restauração de áreas degradadas. São Paulo: Fundação Cargill. p. 109-143.

Guillaumon JR et al., 1989. Plano de manejo do Parque Estadual da Ilha Anchieta. São Paulo: Instituto Florestal. 130 p. (Série Registros).

Hammitt WE \& Cole DN, 1998. Wildland recreation: ecology and management. New York: John Wiley and Sons. 361 p.

Harris B, 2001. Accessibility: concepts and applications. Journal of Transportation and Statistics, 4(2):15-30.

Ingram DR, 1971. The concept of accessibility: a search for an operational form. Regional Studies, 5(2):101-107. http:// dx.doi.org/10.1080/09595237100185131

Jobe R \& White P, 2009. A new cost-distance model for human accessibility and an evaluation of accessibility bias in permanent vegetation plots in Great Smoky Mountains National Park, USA. Journal of Vegetation Science, 20:10991109. http://dx.doi.org/10.1111/j.1654-1103.2009.01108.x

Joppa LN, Loarie SR \& Pimm SL, 2008. On the protection of 'protected areas'. Proceedings of the National Academy of Sciences, 105:6673-6678. PMid:18451028. PMCid:2365567. http://dx.doi.org/10.1073/pnas.0802471105

Kinker S, 2005. Ecoturismo e conservação da natureza em parques nacionais. Campinas: Papirus. 224 p.

Leung YF \& Marion JL, 2000. Recreation impacts and management in wilderness: a state-of-knowledge review. In: Cole DN et al. (eds.). Wilderness science in a time of change. In: Proceedings Rocky Mountain Research Station - RMRS-P-15; 2000, Ogden. Ogden: USDA Forest Service, Rocky Mountain Research Station, p. 23-48.

Liddle MJ, 1997. Recreation ecology: the ecological impact of outdoor recreation and ecotourism. London: Chapman and Hall. 664 p.

Lin JP, 2009. The functional linkage index: a metric for measuring connectivity among habitat patches using least-cost distances. Journal of Conservation Planning, 5:28-37.
Mason P, 2008. Tourism impacts, planning, and management. 2th ed. Oxford: Elsevier. 289 p.

Mitchell A, 1999. The ESRI guide to GIS analysis: geographical patterns and relationships. Redlands: ESRI Press.

Nagendra H, Southworth J \& Tucker C, 2003. Accessibility as a determinant of landscape transformation in western Honduras: linking pattern and process. Landscape Ecology, 18:141-158. http://dx.doi. org/10.1023/A:1024430026953

Newsome D, Moore SA \& Dowling RK, 2002. Natural area tourism: ecology, impacts and management. Clevedon: Channel View Publications. 340 p.

Newsome D, Dowling RK \& Moore SA, 2005. Wildlife Tourism. Clevedon: Channel View Publications. 299 p.

Orams MBA, 2002. Feeding wildlife as a tourism attraction: a review of issues and impacts. Tourism Management, 23:281293. http://dx.doi.org/10.1016/S0261-5177(01)00080-2

Peres CA \& Lake IR, 2003. Extent of nontimber resource extraction in tropical forests: accessibility to game vertebrates by hunters in the Amazon Basin. Conservation Biology, 17(2): 521-535.

Pigram JJ \& Jenkins JM, 2006. Outdoor recreation management. 2th ed. Oxford: Routledge. 329 p.

Pinto N \& Keitt T, 2009. Beyond the least-cost path: evaluating corridor redundancy using a graph-theoretic approach. Landscape Ecology, 24:253-266. http://dx.doi.org/10.1007/ s10980-008-9303-y

Reis A et al., 2003. Restauração de áreas degradadas: a nucleação como base para os processos sucessionais. Natureza \& Conservação, 1:28-36.

Saaty TL, 1977. A scaling method for priorities in hierarchical structures. Journal of Mathematical Psychology, 15:234-281. http://dx.doi.org/10.1016/0022-2496(77)90033-5

Terborgh J \& Van Schaik C, 2002. Why the world needs parks. In: Terborgh J et al. (eds.). Making parks work: strategies for preserving tropical nature. Washington: Island Press. p. 3-14.

Theobald DM, 2009. GIS concepts and ArcGIS methods. 4th. ed. Fort Collins: Conservation Planning Technologies.

Theobald DM, Norman JB III \& Newman P, 2010. Estimating visitor use of protected areas by modeling accessibility: a case study in Rocky Mountain National Park, Colorado, USA. Journal of Conservation Planning, 6:1-20.

Vickery J, 1995. Access. In: Sutherland WJ, Hill DA (eds.). Managing habitats for conservation. Cambridge: Cambridge University Press. p. 42-58.

Weber J \& Kwan M, 2003. Evaluating the effects of geographic contexts on individual accessibility: a multilevel approach. Urban Geography, 24(8):647-671. http://dx.doi. org/10.2747/0272-3638.24.8.647 